J. Amer. Soc. Hort SCI. 118(1):101-108. 1993.

\title{
Contribution of Storage and Currently Assimilated Nitrogen to Vegetative and Reproductive Growth of Rabbiteye Blueberry
}

\author{
Keith T. Birkhold and Rebecca L. Darnell \\ Department of Horticultural Sciences, University of Florida, Gainesville, FL 32611 \\ Additional index words. Vaccinium ashei, fruit development, $\mathrm{N}$ reserves, protein, amino acids, translocation
}

\begin{abstract}
The relative contribution of storage and currently assimilated $\mathbf{N}$ to reproductive and vegetative growth of 'Bonita' and 'Climax' rabbiteye blueberry ( Vaccinium ashei Reade) was estimated immediately before and during the fruit development period. Total and storage $N$ decreased in roots and shoots of both cultivars during dormancy and early fruit development. The principle $N$ storage form appeared to be protein, as indicated by a significant decline in total shoot and root protein during this same period. Storage $\mathbf{N}$ from roots and shoots in both cultivars was remobilized to flowers and/or fruit and new vegetative growth. At anthesis, $90 \%$ of the total $\mathrm{N}$ present in reproductive organs was estimated to come from storage $\mathrm{N}$. By fruit maturity, $\approx 50 \%$ of the accumulated $\mathrm{N}$ was derived from storage pools. Storage $N$ contributed $90 \%$ of the total $N$ in developing vegetative growth of 'Bonita' at leaf budbreak, which is concomitant with floral budbreak for this cultivar. Developing vegetative growth of 'Climax' at leaf budbreak, which occurs $\approx 4$ weeks after floral budbreak, derived $\approx 65 \%$ of its total $N$ from storage and $35 \%$ from currently assimilated $N$. By fruit maturity, contribution of storage $N$ to new vegetative growth had decreased to $\approx 20 \%$ in both cultivars, indicating that currently assimilated $N$ became the principal $N$ supply as vegetative growth became more established. Differences in timing of floral and vegetative budbreak between the two cultivars did not appear to affect allocation of either storage or currently assimilated $N$ to new vegetative or reproductive growth.
\end{abstract}

Two sources of $\mathrm{N}$ are important in perennial crops: that which has been taken up during the previous year(s) and stored (i.e., storage $\mathrm{N}$ ) and that currently available from the soil. Assessing the relative importance of storage and currently assimilated $\mathrm{N}$ pools to vegetative and reproductive growth can be approached by tracing either storage $\mathrm{N}$ or the $\mathrm{N}$ taken up by the plant during the current growing season (Deng et al., 1989). ${ }^{15} \mathrm{~N}$-labeling of spring applied fertilizer has been used to monitor current-year N uptake in apple (Malus domestica Borkh.) (Grasmanis and Nicholas, 1971), almond [Prunus dulcis (Mill.) D.A. Webb] (Weinbaum et al., 1984, 1987), walnut ( Juglans regia L.) (Deng et al., 1989), and highbush blueberry ( Vaccinium corymbosum L.) (Retamales and Hanson, 1989). In general, uptake of fertilizer is minimal during dormancy, then increases with spring shoot and leaf expansion. In highbush blueberry, 32\% of the fertilizer applied during dormancy was recovered by the plant during the growing season (Retamales and Hanson, 1989). Leaves accounted for the highest proportion of fertilizer $\mathrm{N}$ in the plant, with moderate amounts located in the crown, roots, and stems produced during the current season. Stems over 2 years old and fruit received the least amount of currently assimilated $\mathrm{N}$.

$\mathrm{N}$-labeling has been used to assess the contribution of storage vs. currently assimilated $\mathrm{N}$ in orange (Citrus sinesis L.) (Legaz et al., 1981) and walnut (Deng et al., 1989). In 'Valencia' orange, flowers acquired $79 \%$ of their $\mathrm{N}$ from storage pools, fruit at fruit set contained $62 \%$, and vegetative growth at the end of the summer flush contained $44 \%$ storage $\mathrm{N}$ (Legaz et al., 1981). The percentage of storage $\mathrm{N}$ accumulated in new vegetative growth declined from $\approx 70 \%$ to $40 \%$ between flowering and the summer flush. In walnut, remobilization of storage $\mathrm{N}$ to new vegetative growth continued throughout the spring

Received for publication 14 Feb. 1992. Accepted for publication 21 July 1992. University of Florida Journal Series no. R-02513. The cost of publishing this paper was defrayed in part by the payment of page charges. Under postal regulations, this paper therefore must be hereby marked advertisement solely to indicate this fact. growth flush, although the extent of remobilization decreased as the spring growth flush progressed (Deng et al., 1989). Before pistillate flower maturation, development of vegetative and reproductive organs depended heavily on storage $\mathrm{N}$, with flowers and vegetative growth acquiring $95 \%$ and $91 \%$, respectively, of their $\mathrm{N}$ from storage pools. Leaves preferentially accumulated currently assimilated $\mathrm{N}$ during expansion; however, walnut fruit subsequently acquired a higher percentage of currently assimilated $\mathrm{N}$ relative to leaves. Although ${ }^{15} \mathrm{~N}$-labeling has been used to assess the efficiency of fertilizer use in highbush blueberry (Retamales and Hanson, 1989), there is no information on the relative contribution of storage vs. currently assimilated $\mathrm{N}$ to reproductive and/or vegetative growth in blueberry.

Amino acids and/or protein are the primary storage forms of $\mathrm{N}$ in plants. Protein has been reported by Tromp (1983) and Tromp and Ovaa (1971) to be the principal form of $\mathrm{N}$ stored in apple. Stassen et al. (1981) suggested that $\mathrm{N}$ is stored as both protein and amino acids in peach [ Prunus persica (L.) Batsch.]. Amino acids have been reported to be the major $\mathrm{N}$ storage form only when plants are under stress (Millard, 1988). Nitrogen storage forms and their remobilization in blueberry have not been previously reported.

The purpose of this study was to compare the relative contribution of storage and currently assimilated $\mathrm{N}$ to reproductive and vegetative growth during the fruit development period for 'Bonita' and 'Climax' rabbiteye blueberries. These cultivars were selected for differences in budbreak pattern; floral and vegetative budbreak occur concomitantly in 'Bonita', while floral budbreak precedes vegetative budbreak in 'Climax'. By selecting cultivars with contrasting spring growth patterns, temporal differences in allocation of storage and currently assimilated $\mathrm{N}$ could be compared. Additionally, the changes of free amino acids and total protein in shoots and roots were determined to assess the importance of these $\mathrm{N}$ storage forms to spring growth.

Abbreviations: DAA, days after anthesis; DW, dry weight. 


\section{Materials and Methods}

Plant material. 'Bonita' and 'Climax' rabbiteye blueberries were propagated by softwood cuttings in May 1988 and field grown from June 1988 until Feb. 1989. Twenty-eight plants of each cultivar were dug, potted into 22-liter pots containing a 1 peat : 1 pine bark mix, pruned to one basal stem, and maintained outdoors in Gainesville, Fla., from Feb. 1989 until plant harvest the following year. During the 1989 growing season, plants were watered as needed and fertilized with $3.5 \mathrm{~g}$ Peters $20 \mathrm{~N}$ 6.1P-11.6K water soluble fertilizer/liter every 2 weeks through July and every 3 weeks from August through the second week of September, when fertilization was stopped. Fertilization at the same rate resumed at anthesis the following spring.

${ }^{15} \mathrm{~N}$ labeling. Labeling of the storage $\mathrm{N}$ pool began after completion of the fertilization regime in September. Labeling was done with nitrate- $\mathrm{N}$ so that residual ${ }^{15} \mathrm{~N}$ could be readily leached from the potting medium. Each plant received $0.6 \mathrm{~g}$ of $\mathrm{N}$ in the form of $\mathrm{KNO}_{3}$, with $4.93 \%$ enrichment of ${ }^{15} \mathrm{~N}$. This amount was equally divided into three aliquots, dissolved in $300 \mathrm{ml}$ of water, and applied on 7 and 21 Oct. and 7 Nov. 1989. Leaf abscission occurred by 4 Jan. Containers were leached before the first plant harvest to remove residual ${ }^{15} \mathrm{~N}$ fertilizer that might be taken up by the plant during the following spring. Analysis immediately before the first plant harvest indicated there was no residual ${ }^{15} \mathrm{~N}$ in the soil.

Plant harvest and handling. Four individual plant replicates from each cultivar were randomly selected and harvested at each of five dates in 1990. The initial plant harvest was during dormancy (2 Feb., 31 days before anthesis), with the second harvest at $80 \%$ anthesis (9 Mar. for both cultivars). The third harvest was 28 days after anthesis (DAA)(6 Apr.), when the majority of fruit drop occurred and vegetative growth differences were manifested between the cultivars. At this time, the vegetative canopy of 'Bonita' was rapidly expanding, while vegetative budbreak in 'Climax' was just beginning. The fourth harvest occurred 51 DAA (29 Apr.), when both cultivars had rapidly expanding vegetative canopies with high $\mathrm{N}$ requirements. The final plant harvest for both cultivars took place at fruit maturity (26 May), 78 DAA. Plants were harvested on these dates and divided into roots, shoots (produced during the previous growing season), flowers or fruit, and new vegetative growth. Roots and shoots formed during 1988 and 1989 contained the labeled storage pools used for the 1990 vegetative and reproductive growth. Leaves that dropped during the fall and winter were collected by encircling each plant with wire mesh. Following fresh weight measurements of all plant parts, samples were freeze dried, weighed, ground through $\mathrm{a} \approx 0.5 \mathrm{~mm}$ square (40 mesh) screen in a Wiley mill, and stored in airtight vials. Fruit subsamples used in determining $\mathrm{N}$ and ${ }^{15} \mathrm{~N}$ content also were oven dried at $60 \mathrm{C}$ for $24 \mathrm{~h}$ before analysis. Analysis of covariance was used for shoot and root dry weight data, using total bud number as the covariate to account for preexperiment variability in plant size.

Control plants. Estimation of storage $\mathrm{N}$ contribution to vegetative and reproductive growth requires that the storage $\mathrm{N}$ pool be homogenously labeled. Eight plants from each cultivar were used as controls to determine if labeling of the $\mathrm{N}$ storage pool was uniform. These plants were labeled with ${ }^{15} \mathrm{~N}$ at the same time as their experimental counterparts; however, extensive dilution of the $\mathrm{N}$ pool by unlabeled $\mathrm{N}$ was prevented by withholding fertilization in the spring. Four plants of each cultivar were randomly sampled at harvest dates four (51 DAA) and five (78 DAA). Analysis of the ${ }^{15} \mathrm{~N}:{ }^{14} \mathrm{~N}$ ratios in shoots and roots of dormant plants and fruits of control plants was used to determine if the storage $\mathrm{N}$ had been homogeneously labeled. A constant ratio in shoots and roots of dormant plants, and fruit of control plants throughout the experimental period, indicated that storage $\mathrm{N}$ pools were uniformly labeled.

Nitrogen analysis. Nitrogen content was determined by combustion of $3 \mathrm{mg}$ dried tissue, followed by oxidation, and quantification of the evolved $\mathrm{N}_{2}$ gas on a Carlos Erba Model NA 1500 gas chromatograph (Carlo Erba Strumentavione, Milan, Italy) (Birkhold et al., 1992). The percentage of ${ }^{15} \mathrm{~N}$-nitrogen was determined by mass spectrometer (Vaccume Generators 602E, England). Analysis of covariance was used for plant N content, using fall leaf $\mathrm{N}$ concentration as the covariate to account for preexperiment differences in total $\mathrm{N}$ content.

Free amino acid concentrations of shoots and roots were determined by extracting $25 \mathrm{mg}$ of dried tissue in boiling $80 \%$ ethanol (1:100w:v) for $2 \mathrm{~min}$. Extracts were shaken for $20 \mathrm{~min}$, centrifuged, the supernatant decanted, and the pellet re-extracted twice. The supernatants were combined and final volumes measured. Amino acid concentration was quantified via the ninhydrin procedure as described by Marks et al. (1985), using a leucine standard.

Total amino acids (free amino acids and protein amino acids) in shoots and roots were determined by hydrolyzing 20-mg dry tissue in $5 \mathrm{ml}$ of $6 \mathrm{~N} \mathrm{H}_{2} \mathrm{SO}_{4}$ containing $0.1 \%$ phenol (w:v) and $0.05 \%$ B-mercaptoethanol (Ozols, 1990). Sample tubes were flushed with $\mathrm{N}_{2}$ gas, sealed, and incubated at $110 \mathrm{C}$ for $22 \mathrm{~h}$. After being cooled, samples were neutralized with $4.6 \mathrm{ml}$ of $28 \% \mathrm{NaOH}$ (Marks et al., 1985) and analyzed for total amino acids by the procedure described above, with hydrolyzed BSA as the standard. Total protein was calculated by subtracting the free amino acid concentration from the total amino acid concentration.

Calculation of storage $\mathrm{N}$. The quantity of storage and currently assimilated $\mathrm{N}$ within plant parts was estimated using the approach described by Deng et al. (1989). The isotopic labeling of the $\mathrm{N}$ pool during dormancy was used as the value for the storage $\mathrm{N}$ pool and assumes a uniform labeling of all $\mathrm{N}$ pools within the plant. The validity of this assumption was verified by monitoring ${ }^{15} \mathrm{~N}$ levels in control plants throughout the fruit development period, where it was determined that the ${ }^{15} \mathrm{~N}:{ }^{14} \mathrm{~N}$ ratio in shoots and roots of dormant plants, and fruits of the control plants, were constant. The total $\mathrm{N}$ contribution from the storage $\mathrm{N}$ pool was calculated by dividing the excess ${ }^{15} \mathrm{~N}$ found in tissues at subsequent plant harvest dates by the initial excess ${ }^{15} \mathrm{~N}$ measured at the first plant harvest (2 Feb.), and multiplying by the total $\mathrm{N}$ per plant part. Currently assimilated $\mathrm{N}$ was determined by subtracting the storage $\mathrm{N}$ from the total.

\section{Results}

Plant development. Root and shoot dry weight (DW) in 'Bonita' declined significantly from 60 to $40 \mathrm{~g}$ and 40 to $30 \mathrm{~g}$, respectively, between dormancy (31 days preanthesis or -31 DAA) and anthesis (0 DAA), then remained steady until increasing slightly between 51 DAA and fruit maturity (78 DAA) (Fig. 1A). 'Climax' root DW declined continuously between dormancy and fruit maturity, decreasing from 70 to $40 \mathrm{~g}$ (Fig. 1B). 'Climax' shoot DW declined between dormancy (-31 DAA) and 51 DAA before increasing at fruit maturity (78 DAA).

Spring vegetative growth of 'Bonita' began concomitantly with floral budbreak, with the most rapid increase in new vegetative growth occurring between 28 and 51 DAA (Fig. 1C). The rate of vegetative DW accumulation decreased between 51 


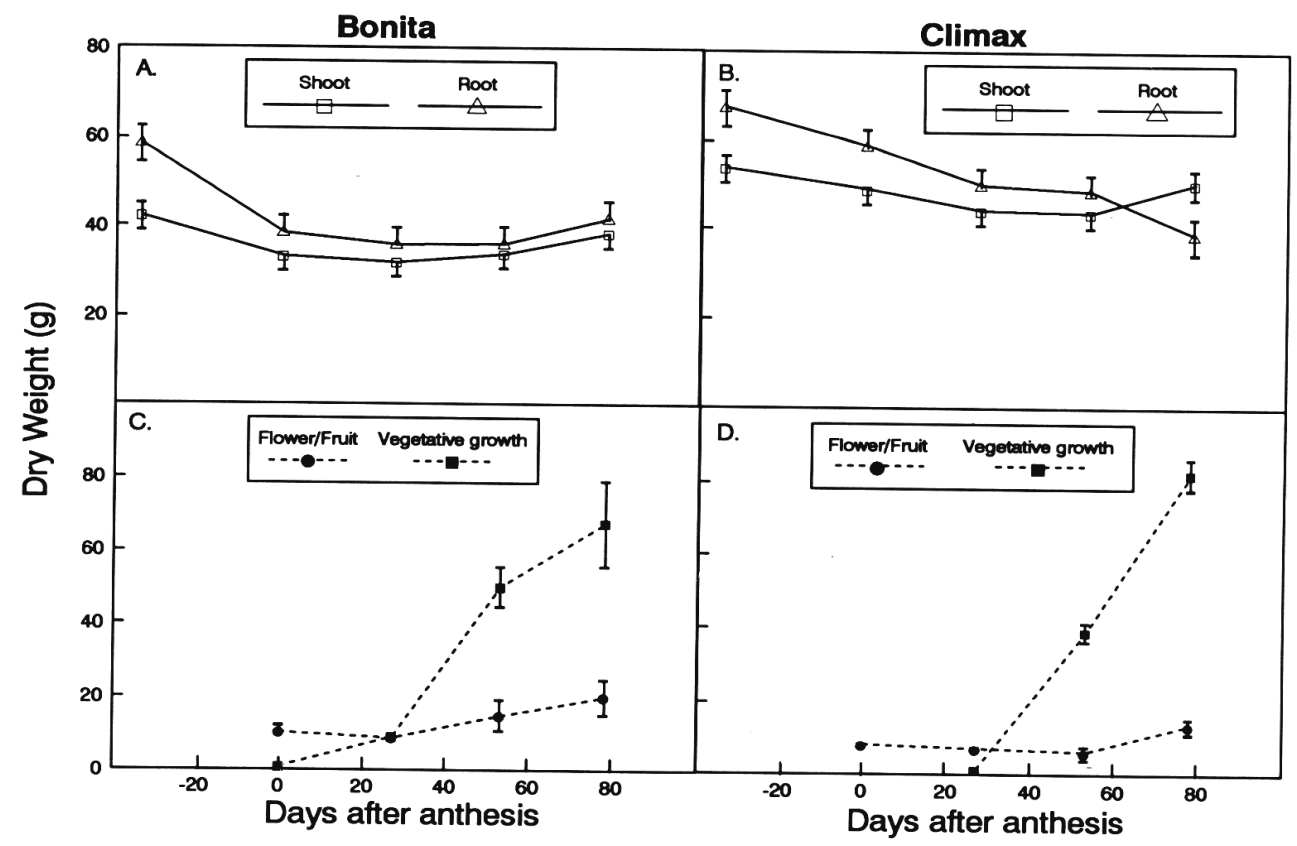

Fig. 1. Dry weights of rabbiteye blueberry from dormancy ( $-31 \mathrm{DAA})$ to fruit maturity (78 DAA): shoot and root DW for 'Bonita' (A) and 'Climax' (B), flower and/or fruit and new vegetative growth DW for 'Bonita' (C) and 'Climax' (D) (means \pm SE, $n=4, S E$ bars present
only when larger than symbol).

and 78 DAA. Total spring vegetative growth per plant at fruit maturity (78 DAA) averaged $70 \mathrm{~g}$ DW. Flower and/or fruit DW on a whole plant basis did not change between anthesis and 28 DAA, but began increasing steadily 28 DAA. On an individual fruit basis, DW of 'Bonita' fruit increased from $\approx 5$ to $185 \mathrm{mg}$ between anthesis and fruit maturity. 'Bonita' plants bore $\approx 1660$ florets per plant at anthesis but only 109 fruit at 78 DAA. Vegetative budbreak in 'Climax' did not begin until 28 DAA (Fig. 1D). Once growth began, however, a rapid linear increase in new shoot and leaf DW was observed throughout the remaining fruit development period. At fruit maturity, total new vegetative growth of 'Climax' averaged $80 \mathrm{~g}$ DW. Total flower and/or fruit DW for 'Climax' plants did not change significantly until after 51 DAA. Individual fruit DW increased from $\approx 7$ to 95 mg between anthesis and fruit maturity. 'Climax' plants carried $\approx 1250$ florets per plant at anthesis but only 143 fruit at 78 DAA.

Nitrogen concentration. Root $\mathrm{N}$ concentration in 'Bonita' remained constant at $\approx 10 \mu \mathrm{g} \cdot \mathrm{mg}^{-1} \mathrm{DW}$ until $28 \mathrm{DAA}$, when it began increasing gradually through fruit maturity (Fig. 2A). Nitrogen concentration in 'Bonita' shoots declined from $\approx 7$ to $4 \mu \mathrm{g} \cdot \mathrm{mg}^{-1} \mathrm{DW}$ during the 31 days leading up to anthesis, then increased to $6 \mu \mathrm{g} \cdot \mathrm{mg}^{-1} \mathrm{DW}$ by fruit maturity (78 DAA). Root $\mathrm{N}$ concentration in 'Climax' rose steadily from $\approx 11 \mu \mathrm{g} \cdot \mathrm{mg}^{-1}$ DW during dormancy (-31 DAA) to $\approx 15 \mu \mathrm{g} \cdot \mathrm{mg}^{-1} \mathrm{DW}$ by fruit maturity (Fig. 2B). 'Climax' shoot $\mathrm{N}$ concentration declined significantly over the 112 day period, decreasing from 8 to $5 \mu \mathrm{g} \cdot \mathrm{mg}^{-1} \mathrm{D} \mathrm{W}$.

Total $\mathrm{N}$ concentration in the earliest developed spring vegetative growth averaged $26 \mu \mathrm{g} \cdot \mathrm{mg}^{-1} \mathrm{DW}$ for both cultivars (Fig. $2 \mathrm{C}$ and $\mathrm{D})$. By 51 DAA, the average $\mathrm{N}$ concentration declined to $15 \mu \mathrm{g} \cdot \mathrm{mg}^{-1} \mathrm{DW}$, where it remained until fruit maturity. Nitrogen concentration in flowers and/or fruit of both cultivars decreased from $20 \mu \mathrm{g} \cdot \mathrm{mg}^{-1}$ at anthesis to $10 \mu \mathrm{g} \cdot \mathrm{mg}^{-1}$ at fruit maturity.

Total shoot and root $\mathrm{N}$ content in 'Bonita' declined from dormancy (-31 DAA) until 28 DAA, then increased through fruit maturity (Fig. 3A). Shoots lost $150 \mathrm{mg}$ and roots lost 280 $\mathrm{mg}$ of $\mathrm{N}$ during the period of decline and gained $\approx 100 \mathrm{mg}$ and $150 \mathrm{mg}$, respectively, during the period of increase. Spring vegetative growth of 'Bonita' acquired $1.0 \mathrm{~g} \mathrm{~N}$ from anthesis to fruit maturity, the most rapid period of gain occurring between 28 and 51 DAA. Reproductive organs accounted for $\approx 220 \mathrm{mg}$ of the total plant $\mathrm{N}$ content from anthesis through fruit maturity. On an individual fruit basis, $\mathrm{N}$ content increased from $0.13 \mathrm{mg}$ $\mathrm{N} /$ berry at anthesis, to $0.28 \mathrm{mg}$ at $28 \mathrm{DAA}, 1.30 \mathrm{mg}$ at 51 DAA, and $1.85 \mathrm{mg}$ at fruit maturity (78 DAA) (Fig.4).

Total shoot and root $\mathrm{N}$ in 'Climax' declined from dormancy (-31 DAA) to fruit maturity (78 DAA), with shoots and roots losing 170 and $150 \mathrm{mg}$ of $\mathrm{N}$, respectively (Fig. 3B). Unlike in 'Bonita', no period of rapid $\mathrm{N}$ loss or gain was observed in 'Climax' roots. Nitrogen content in spring vegetative growth of 'Climax' increased rapidly, gaining $1.1 \mathrm{~g}$ in 50 days. Total $\mathrm{N}$ content in 'Climax' fruit declined from 180 to $90 \mathrm{mg}$ between 28 and 51 DAA, then increased to $155 \mathrm{mg}$ at fruit maturity. Nitrogen content of individual fruit increased from $0.14 \mathrm{mg}$ at anthesis to $0.34 \mathrm{mg}$ at $28 \mathrm{DAA}, 0.54 \mathrm{mg}$ at $51 \mathrm{DAA}$, and 1.09 $\mathrm{mg}$ at fruit maturity (Fig. 4).

Isotopic labeling of the $\mathrm{N}$ pool in both cultivars decreased for all plant parts between dormancy (-31 DAA) and fruit maturity (78 DAA) (Fig. $3 \mathrm{C}$ and D). Isotopic percentages in new vegetative growth declined at a greater rate than in other plant parts for both cultivars.

Based on total $\mathrm{N}$ content and percent ${ }^{15} \mathrm{~N}$, total storage $\mathrm{N}$ was calculated for each plant part. Amounts of storage $\mathrm{N}$ in shoots and roots of 'Bonita' decreased sharply from 280 to 130 $\mathrm{mg}$ and 620 to $390 \mathrm{mg}$, respectively, during the interval leading up to anthesis, indicating remobilization of this $\mathrm{N}$ source (Fig. $3 \mathrm{E})$. There was no significant decline in shoot storage $\mathrm{N}$ after 28 DAA; however, root storage $\mathrm{N}$ continued to decline slightly throughout the fruit development period, reaching $260 \mathrm{mg}$ by 


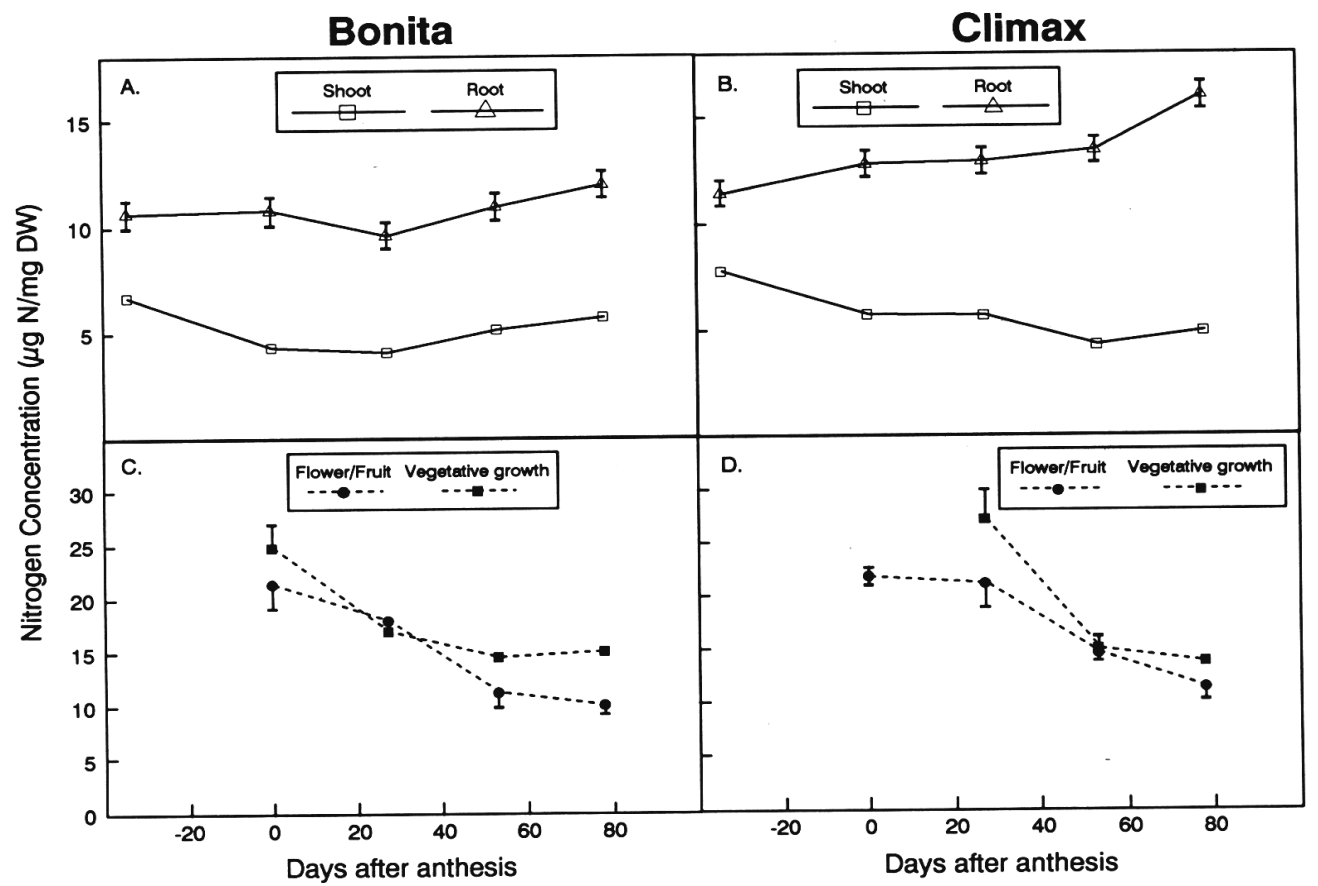

Fig. 2. Nitrogen concentration in rabbiteye blueberry from dormancy ( -31 DAA) to fruit maturity (78 DAA): shoot and root N concentration for 'Bonita' (A) and 'Climax' (B), flower and/or fruit and new vegetative growth $\mathrm{N}$ concentration for 'Bonita' (C) and 'Climax' (D) (means $\pm \mathrm{SE}, \mathrm{n}=4$, SE bars present only when larger than symbol).

fruit maturity (78 DAA). Total storage $\mathrm{N}$ content in flowers and/or young fruit was highest at anthesis $(200 \mathrm{mg})$ and declined to $100 \mathrm{mg}$ by fruit maturity, due to flower and fruit abscission. On an individual fruit basis, storage $\mathrm{N}$ was remobilized to fruit up to 51 DAA, after which $\mathrm{N}$ contribution to fruit arose solely from currently assimilated $\mathrm{N}$ (Table 1). Storage $\mathrm{N}$ accounted for $92 \%$ of the total $\mathrm{N}$ supplied to 'Bonita' reproductive organs by anthesis. This value decreased to $84 \%$ at 28 DAA, $69 \%$ at $51 \mathrm{DAA}$, and $48 \%$ at fruit maturity. The amount of storage $\mathrm{N}$ remobilized to new vegetative growth increased linearly up to 51 DAA, before plateauing at $\approx 200 \mathrm{mg}$. From 52 to 78 DAA, essentially all the $\mathrm{N}$ imported into new vegetative growth was derived from currently assimilated $\mathrm{N}$ (Table 1 ). New vegetative growth of 'Bonita' derived $91 \%$ of its total $\mathrm{N}$ from storage $\mathrm{N}$ at anthesis. This proportion declined to $58 \%$ at 28 DAA, $29 \%$ at 51 DAA, and $19 \%$ at fruit maturity, as currently assimilated, unlabeled $\mathrm{N}$ was taken up.

Storage $\mathrm{N}$ pools in shoots and roots of 'Climax' declined steadily from $\approx 400$ to $100 \mathrm{mg}$ and 800 to $300 \mathrm{mg}$ between dormancy (-31 DAA) and fruit maturity (78 DAA), respectively, again indicating remobilization (Fig. 3F). Storage $\mathrm{N}$ in flowers and/or fruit declined from a maximum of $160 \mathrm{mg}$ at anthesis to $75 \mathrm{mg}$ at $78 \mathrm{DAA}$ due to fruit abscission. The percentage contribution of storage $\mathrm{N}$ to the total $\mathrm{N}$ in 'Climax' flowers and/or fruit was similar to that of 'Bonita', decreasing from $87 \%$ at anthesis to $67 \%$ at 28 and 51 DAA and $49 \%$ at fruit maturity. Unlike the situation in 'Bonita' fruit, however, the amount of storage $\mathrm{N}$ remobilized to 'Climax' fruit was similar throughout all three stages of fruit development (Table 1). Remobilization of storage $\mathrm{N}$ contributed a decreasing percentage of the total $\mathrm{N}$ in new vegetative growth, declining from $66 \%$ at 28 DAA (i.e., vegetative budbreak for 'Climax') to $30 \%$ at 51 DAA, and $20 \%$ at fruit maturity. However, absolute amounts of storage $\mathrm{N}$ remobilized to new vegetative growth increased from $30 \mathrm{mg}$ at $28 \mathrm{DAA}$ to $\approx 200 \mathrm{mg}$ at fruit maturity (78 DAA).

Protein content. Total root protein concentration in 'Bonita' declined sharply between dormancy (-31 DAA) and 28 DAA, decreasing from $\approx 100 \mu \mathrm{g} \cdot \mathrm{mg}^{-1} \mathrm{DW}$ to $60 \mu \mathrm{g} \cdot \mathrm{mg}^{-1}$ (Fig. $5 \mathrm{~A}$ ). Root protein concentration then increased rapidly, reaching a final concentration of $115 \mu \mathrm{g} \cdot \mathrm{mg}^{-1}$. Total shoot protein concentration declined gradually from 65 to $40 \mu \mathrm{g} \cdot \mathrm{mg}^{-1} \mathrm{D} \mathrm{W}$ throughout fruit development, with the largest decrease occurring between dormancy (-31 DAA) and anthesis (0 DAA). Although total protein concentrations changed in shoot and root tissue throughout fruit development, there were no concomitant changes in the concentration of total amino acids.

Total protein concentration in shoots and roots of 'Climax' declined significantly between dormancy (-31 DAA) and anthesis, from an average of 70 to $40 \mu \mathrm{g} \cdot \mathrm{mg}^{-1} \mathrm{DW}$ and 70 to 50 $\mu \mathrm{g} \cdot \mathrm{mg}^{-1} \mathrm{DW}$ for shoots and roots, respectively (Fig. 5B). Changes in shoot protein concentration following anthesis were not significant. However, root protein concentration increased from 50 to $60 \mu \mathrm{g} \cdot \mathrm{mg}^{-1}$ between 28 and $51 \mathrm{DAA}$. Free amino acid concentration in shoots did not change significantly during fruit development, however; free amino acid concentration in roots increased significantly from $\approx 20$ to $40 \mu \mathrm{g} \cdot \mathrm{mg}^{-1} \mathrm{DW}$. Amino acid and total protein concentrations for both cultivars were consistently higher in roots than in shoots.

In 'Bonita', shoots lost $1.5 \mathrm{mg}$ protein between dormancy (-31 DAA) and anthesis, after which the protein content remained relatively constant (Fig. 5C). Total root protein decreased from $\approx 6$ to $2 \mathrm{mg}$ between dormancy ( $-31 \mathrm{DAA})$ and $28 \mathrm{DAA}$, then increased to $\approx 4 \mathrm{mg}$ by fruit maturity (78 DAA). Total protein in 'Climax' declined from 4 to $2 \mathrm{mg}$ and 5 to 3 $\mathrm{mg}$ for shoots and roots, respectively, during the interval leading up to anthesis (Fig. 5D). There was little change in total root 


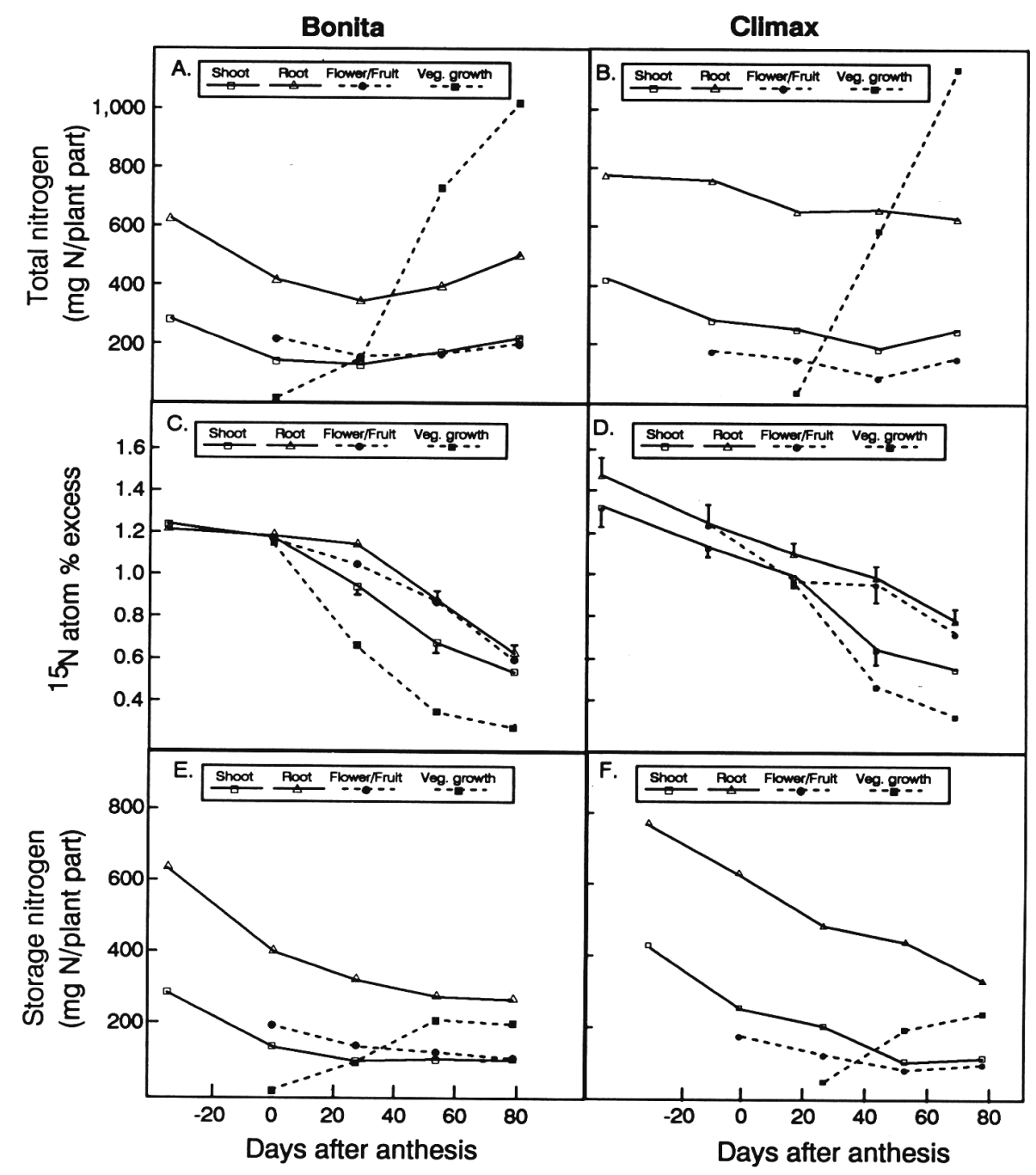

Fig. 3. Nitrogen content in rabbiteye blueberry from dormancy (-31 DAA) to fruit maturity (78 DAA): total N per plant part for 'Bonita' (A) and 'Climax' (B), ${ }^{15} \mathrm{~N}$ atom percent excess for 'Bonita' (C) and 'Climax' (D) (means $\pm \mathrm{SE}, \mathrm{n}=4$, SE bars present only when larger than symbol), and storage $N$ per plant part for 'Bonita' (E) and 'Climax' (F).

and shoot free amino acids during fruit development in either cultivar, with the exception of free amino acids in 'Climax' roots, which increased slightly between dormancy (-31 DAA) and anthesis.

\section{Discussion}

Losses in shoot and root DW, particularly in 'Bonita' roots between dormancy (-31 DAA) and anthesis, suggest that storage compounds are being remobilized to new growth during this period. Much of the loss in shoot and root DW is probably due to remobilization and respiration of carbohydrates, which comprise $25 \%$ to $45 \%$ of DW in woody plants (Tromp, 1983). However, the decline in total and storage $\mathrm{N}$ in roots and shoots of both cultivars from dormancy (-31 DAA) until 28 DAA suggests significant remobilization of $\mathrm{N}$ compounds as well. The large decrease in storage $\mathrm{N}$ and protein in roots of both cultivars indicates that roots were the primary storage site. In general, the percentage decline in levels of total and storage $\mathrm{N}$ in roots and shoots of 'Bonita' was similar through 28 DAA, suggesting little uptake of external $N$ until this time. Similarly, Weinbaum et al. (1978) found that nitrate uptake by prune ( Prunus domestica L.) trees was low during bud swell in the spring, increased dramatically during rapid shoot elongation, and remained high until leaf abscission in the fall. They reported a high correlation between nitrate uptake and the presence of leaves. Such a correlation was not readily apparent in our study. Storage $\mathrm{N}$ in roots of 'Climax' declined by $40 \%$ through $28 \mathrm{DAA}$, while total $\mathrm{N}$ declined by only $20 \%$, suggesting that external $\mathrm{N}$ was taken up earlier by 'Climax' than by 'Bonita', even though the vegetative canopy of 'Bonita' was more fully established. This difference may be due to the larger root system of 'Climax' compared to 'Bonita' throughout early development.

Storage N content in 'Bonita' roots and 'Climax' roots and shoots continued to decline throughout fruit maturity, even as total $\mathrm{N}$ levels in these plant parts remained constant or increased. Thus, $\mathrm{N}$ stored from the previous growing season was used to support new growth even when currently supplied $\mathrm{N}$ was available. Similarly, Oland (1959) reported that N storage pools in apple trees decreased throughout the growing season, despite adequate external $\mathrm{N}$ supply. 


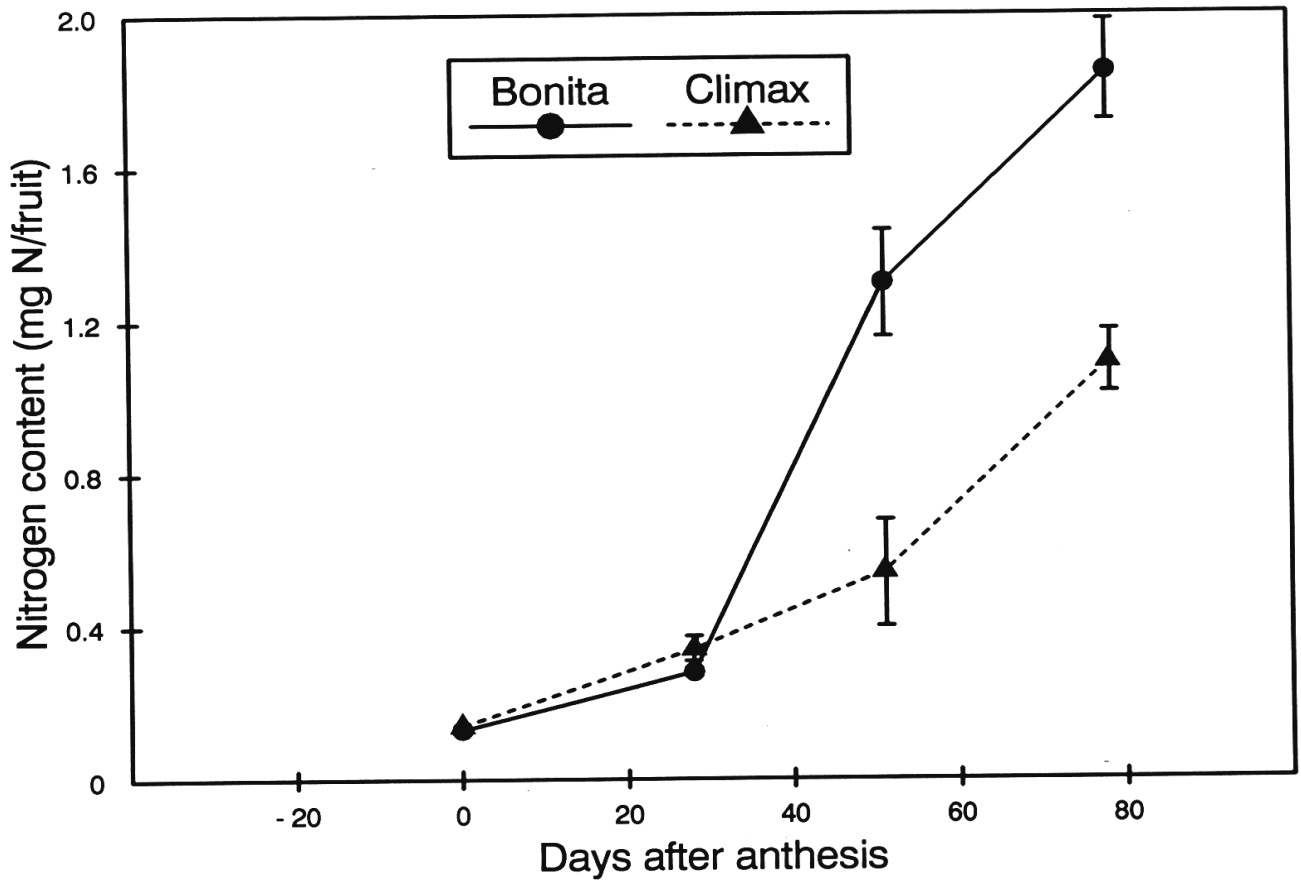

Fig. 4. Nitrogen content in rabbiteye blueberry fruit from anthesis (0 DAA) to fruit maturity (78 DAA) (means $\pm S E, n=4, S E$ bars present only when larger than symbol).

Table 1. Estimated $\mathrm{N}$ cost and $\mathrm{N}$ supply for fruit and vegetative (veg.) growth of rabbiteye blueberry at various developmental stages.

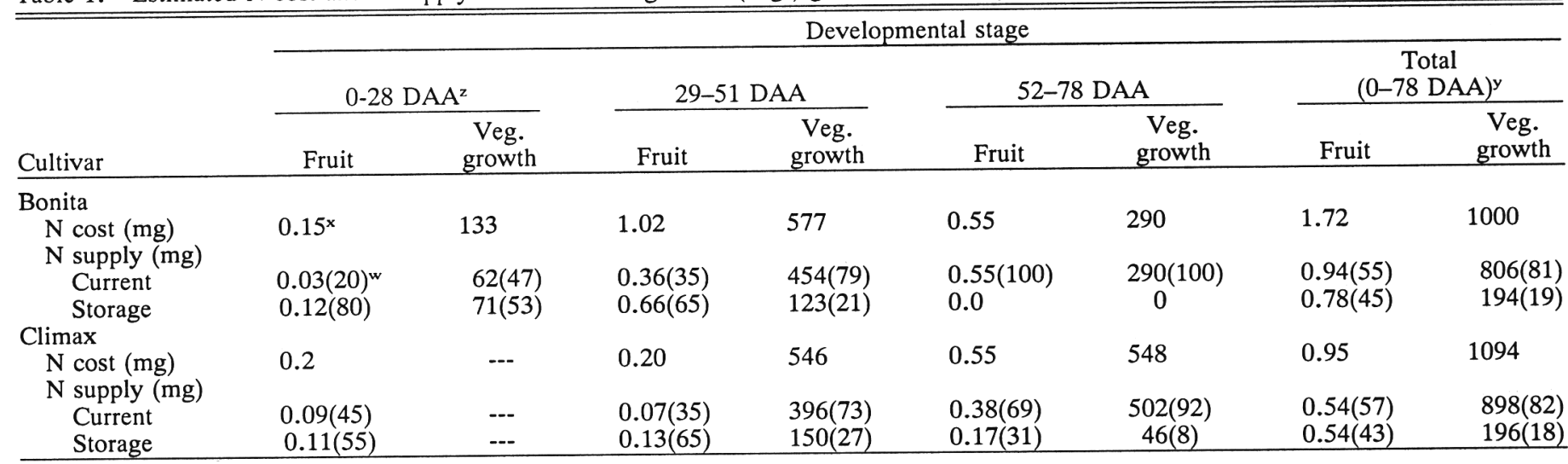

${ }^{2} \mathrm{DAA}=$ days after anthesis.

yDifferences in absolute and percent $\mathrm{N}$ between the total $\mathrm{N}$ in fruit or vegetative growth at fruit maturity as described in the text and in Fig. 4 , and the total $\mathrm{N}$ accumulated between 0 and $78 \mathrm{DAA}$ as depicted in this table represent $\mathrm{N}$ present in floral or vegetative buds before budbreak. vValues represent milligrams $\mathrm{N}$ per fruit or milligrams $\mathrm{N}$ in new vegetative growth accumulated during each stage of development. Data were calculated from Fig. 3 .

wValues in parentheses represent the percentage contribution of storage or currently assimilated $\mathrm{N}$ for each stage of development.

Protein $\mathrm{N}$ appears to be the principle $\mathrm{N}$ storage form in blueberry, as indicated by the significant decline in shoot and root protein during the early stages of reproductive and vegetative development for both cultivars. Proteins are reported to be a primary N storage form in other fruit crops (Stassen et al., 1981; Tromp, 1983; Tromp and Ovaa 1971), as well as in other deciduous, woody perennials (Langheinrich and Tischner, 1991; Wetzel et al., 1989). The decrease in total protein concentration and content in shoots and roots of both cultivars between dormancy (-31 DAA) and 28 DAA mirrored the decrease in storage $\mathrm{N}$, and suggests that remobilization of storage protein may be a particularly important source of $\mathrm{N}$ for new growth before establishment of a complete vegetative canopy. The increase in protein concentration and content after 28 DAA in roots of 'Bonita' (but to a much more limited extent in roots of 'Climax') may reflect the decreased sink demand and/or increased source supply of $\mathrm{N}$ after establishment of the vegetative canopy. This pattern of protein degradation and accumulation in storage tissue is similar to that found by Coleman et al. (1991) in stems of Populus deltoides Bart. ex Marsh. They suggested that storage protein accumulation may be regulated, at least partially, by source/sink relationships. 


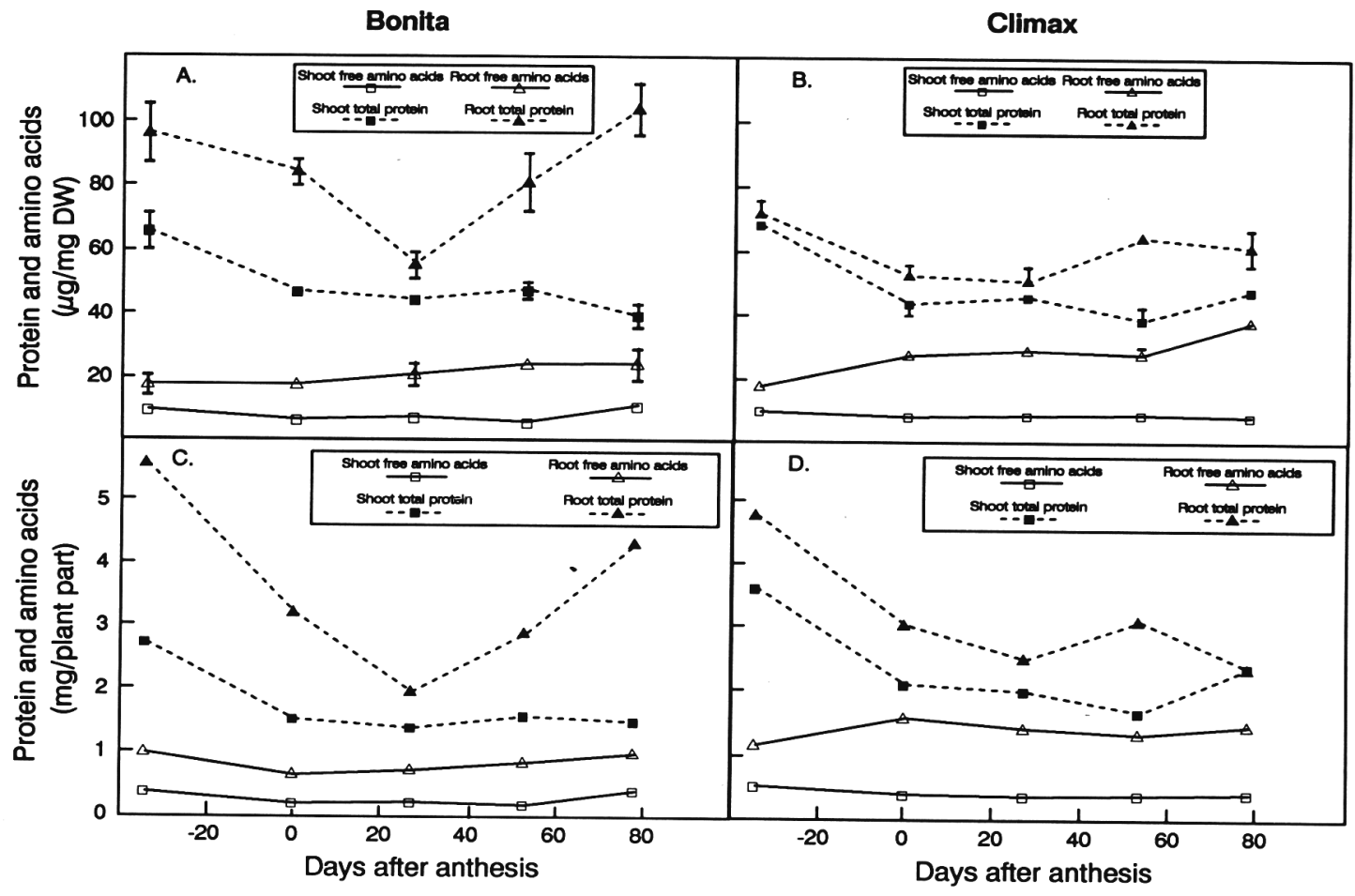

Fig. 5. Protein and free amino acids in shoots and roots of rabbiteye blueberry from dormancy (-31 DAA) to fruit maturity (78 DAA): protein and amino acid concentration in 'Bonita' (A) and 'Climax' $(\mathbf{B})$ (means \pm SE, $n=4$, SE bars present only when larger than symbol), protein and amino acid content in 'Bonita' (C) and 'Climax' (D).

Nitrogen concentration in reproductive and new vegetative growth was highest early in development and decreased with time. This result resembles findings by Retamales and Hanson (1989) for blueberry and Taylor and van den Ende (1969) for peach and suggests a strong $\mathrm{N}$ demand by rapidly growing organs, probably due to high rates of nucleic acid and protein synthesis in dividing tissues.

Storage $\mathrm{N}$ from shoots and roots in both cultivars was remobilized to flowers and young fruit; $90 \%$ of the total $\mathrm{N}$ present in reproductive organs at anthesis was estimated to come from storage $\mathrm{N}$. Total and storage $\mathrm{N}$ content of the crop decreased after anthesis as a result of petal and fruit drop. On an individual fruit basis, total $\mathrm{N}$ content increased throughout development for both cultivars. Storage $\mathrm{N}$ content increased throughout development in 'Climax' fruit, indicating that remobilization of storage $\mathrm{N}$ into fruit continued throughout fruit development. However, storage $\mathrm{N}$ remobilization to 'Bonita' fruit ceased by 51 DAA, with currently assimilated $\mathrm{N}$ supplying the $\mathrm{N}$ requirements of the fruit during the last stage of growth. Currently assimilated $\mathrm{N}$ supplied an increasing percentage of total $\mathrm{N}$ in developing fruit, increasing from $\approx 10 \%$ at anthesis to $50 \%$ at fruit maturity for both cultivars. Deng et al. (1989) also concluded that currently assimilated $\mathrm{N}$ became increasingly important for walnut fruits later in development. New vegetative growth appeared to be the largest sink for $\mathrm{N}$ following anthesis, with $\approx 50 \%$ of the total plant $\mathrm{N}$ present in current season's vegetative growth at 78 DAA. Vegetative growth of blueberry also relied on $\mathrm{N}$ storage pools, particularly during early expansion of the shoots and leaves. The percentage contribution of storage $\mathrm{N}$ declined from vegetative budbreak to fruit maturity, suggesting that currently assimilated $\mathrm{N}$ became the principal supply of $\mathrm{N}$ as vegetative growth became more established. The greater di- lution of ${ }^{15} \mathrm{~N}$ in vegetative growth compared to other plant parts suggests preferential supply of currently assimilated $\mathrm{N}$ to vegetative growth, which is likely due to higher transpiration rates in leaves compared to other tissues (Pate, 1980). Deng et al. (1989) found that currently supplied $\mathrm{N}$ accumulated preferentially in vegetative compared to reproductive tissue in walnut during leaf expansion. Following leaf expansion, however, developing fruits accumulated a higher percentage of currently supplied $\mathrm{N}$ than did leaves. This pattern did not hold with blueberry, where currently assimilated $\mathrm{N}$ accounted for a higher percentage of the total $\mathrm{N}$ for vegetative compared to reproductive growth at all stages of development. This difference may reflect the overall lower $\mathrm{N}$ requirements of blueberry fruit (Birkhold et al., 1992) compared to nut crops (calculated from Weinbaum et al., 1984).

There appeared to be little effect of temporal differences in floral and vegetative budbreak on allocation of storage vs. currently assimilated $\mathrm{N}$ to new vegetative or reproductive growth in blueberry. Nor was there any significant effect of budbreak differences on $\mathrm{N}$ concentration in the various plant parts throughout fruit development. Although there was a difference in patterns of root protein degradation and accumulation between the two cultivars, the apparent delay in protein accumulation observed in 'Climax' roots, although possibly related to the delay in vegetative budbreak, does not appear to limit either vegetative or reproductive growth of blueberry.

\section{Literature Cited}

Birkhold. K.T., K.E. Koch, and R.L. Darnell. 1992. Carbon and nitrogen economy of developing rabbiteye blueberry fruit. J. Amer. Soc. Hort. Sci. 117:139-145.

Coleman, G.D., T.H.H. Chen, S.G. Ernst, and L. Fuchigami. 1991. 
Photoperiod control of poplar bark storage protein accumulation. Plant Physiol. 96:686-692.

Deng X., S.A. Weinbaum, T.M. DeJong, and T.T. Muraoka. 1989. Utilization of nitrogen from storage and current-year uptake in walnut spurs during the spring flush of growth. Physiol. Plant. 75:492-498.

Grasmanis, V.O. and D.J.D. Nicholas. 1971. Annual uptake and distribution of ${ }^{15} \mathrm{~N}$-labelled ammonia and nitrate in young 'Jonathan'/ MM104 apple trees grown in solution cultures. Plant Soil 35:95$1 \quad 12$.

Langheinrich, U. and R. Tischner. 1991. Vegetative storage proteins in poplar. Plant Physiol. 97:1017-1025.

Legaz, F., E.P. Millo, E.P. Yufera, and C. Gil. 1981. Dynamics of ${ }^{15} \mathrm{~N}$-labeled nitrogen nutrients in 'Valencia' orange trees. Proc. Intl. Soc. Citricult. 2:375-582.

Marks, D.L., R. Buchsbaum, and T. Swain. 1985. Measurement of total protein in plant samples in the presence of tannins. Anal. Biochem. 147:136-143.

Millard, P. 1989. The accumulation and storage of nitrogen by herbaceous plants. Plant Cell Environ. 11:1-8.

Oland, K. 1959. Nitrogenous reserves in apple trees. Physiol. Plant. 12:594-645.

Ozols, J. 1990. Amino acid analysis. Methods in enzymology. 182:587601.

Pate, J.S. 1980. Transport and partitioning of nitrogenous solutes. Ann. Rev. Plant Physiol. 31:313-340.

Retamales, J.B. and E.J. Hanson. 1989. Fate of ${ }^{15} \mathrm{~N}$-labeled urea ap plied to mature highbush blueberries. J. Amer. Soc. Hort. Sci. 114:920-923.
Stassen, P.J., H.W. Stindy, D.K. Strydom, and J.H. Terblanche. 1981. Seasonal changes in nitrogen fractions of young 'Kakamas' peach trees. Agroplantae 13:63-72.

Taylor, B.K. and B. van den Ende. 1969. The nitrogen nutrition of the peach tree. IV. Storage and mobilization of nitrogen in mature trees. Austral. J. Agr. Res. 20:869-881.

Tromp, J. 1983. Nutrient reserves in roots of fruit trees, in particular carbohydrates and nitrogen. Plant Soil 71:401-413.

Tromp, J. and J.C. Ovaa. 1971. Spring mobilization of storage nitrogen in isolated shoot sections of apple. Physiol. Plant. 25:1622.

Weinbaum, S.A., I. Klein, F.E. Broadbent, W.C. Micke, and T.T. Muraoka. 1984. Use of isotopic nitrogen to demonstrate dependence of mature almond trees on annual uptake of soil nitrogen. J. Plant Nutr. 7:975-990.

Weinbaum, S.A., I. Klein, and T.T. Muraoka. 1987. Use of nitrogen isotopes and a light-textured soil to assess annual contributions of nitrogen from soil and storage pools in mature almond trees. J. Amer. Soc, Hort. Sci. 112:526-529.

Weinbaum, S.A., M.L. Merwin, and T.T. Muraoka. 1978. Seasonal variation in nitrate uptake efficiency and distribution of absorbed nitrogen in non-bearing prune trees. J. Amer. Soc. Hort. Sci. 103:516519 .

Wetzel, S., C. Demmers, and J.S. Greenwood. 1989. Seasonally fluctuating bark proteins are a potential form of nitrogen storage in three temperate hardwoods. Planta 178:275-281. 